\title{
MODELING POTENTIAL SUITABLE TIGER HABITAT IN SARISKA NATIONAL PARK (INDIA) USING HABITAT SUITABILITY AND INTEGRATED GEOSPATIAL APPROACH
}

\author{
Pavan Kumar ${ }^{1, *}$, Suman Sinha ${ }^{2}$, Manmohan Dobriyal ${ }^{1}$, A. K. Pandey ${ }^{1}$, RS Tomar ${ }^{1}$ and Meenu Rani ${ }^{3}$ \\ ${ }^{1}$ College of Horticulture and Forestry, Rani Lakshmi Bai Central Agricultural University, Jhansi-284003, India \\ ${ }^{2}$ Department of Geography, Amity University, Kolkata, India \\ ${ }^{3}$ Department of Geography, Kumaun University, Nainital, Uttarakhand, India
}

\section{Research Article}

Received: 15.09.2020

Revised: 28.09.2020

Accepted: 15.10.2020

\begin{abstract}
The aim of the study is to model the actual/potential wildlife habitat suitability with or without the current human impacts with integrated Geospatial technology. The research area is the Sariska National Park, Rajasthan. In order to determine the suitable site, the parameters considered are slope, elevation, aspect, vegetation types and density, proximity to the water bodies, roads and settlements, availability of food and interaction with other species in the study area with other secondary data like population data and habitat use data. A methodology integrating several forms of remotely sensed data into a Geographic Information Systems (GIS) model is developed that identifies suitable sites. Proximity and overlay analysis are used with GIS modeling to assess the suitable sites. Habitat suitability index (HSI) is generated that determines the suitable site for wildlife habitat considering the human interventions and man-wildlife conflicts in Sariska National Park. The outcome may fit with conservation strategies of wildlife in the coming future to be taken by authorities. The area is found to be highly suitable for tiger habitat and suitable for their relocation. HSI $>0.8$ corresponds to $49.057 \mathrm{~km} 2$ which is the most suitable for tiger habitat corresponding to $3.8 \%$ of the total study area on an average.
\end{abstract}

Keywords: Habitat suitability, Overlay analysis, GIS, HIS.

\section{INTRODUCTION}

Forests are at constant risk due to its transformation for agriculture and pastures and its exposure to forest fire, pest and disease outbreak. All these threats become sources of CO2. However, it is not always the case (Srivastava, 2009; Vahidnia et al., 2008; Wuver et al., 2006; Nathan, 2007). Some areas under forest are being converted to plantations and increasingly becoming carbon sinks. Emissions of $\mathrm{CO} 2$ as a result of transformation of forest into agriculture were higher than the burning of fossil fuels prior to this century (Houghton, 2009; Goodale et al., 2002). Forests are significant as these reduce concentration of carbon dioxide in the atmosphere and help in mitigating climate change. Therefore, management of forest resources can help in conserving biodiversity, water and soil within forest ecosystem. Forests capture carbon from the atmosphere through the process of photosynthesis. These convert photosynthate into biomass through the processes of respiration and decomposition and emit carbon back into the atmosphere. Forests can play an important part in preventing increase of greenhouse gases in the atmosphere (Hernández-Stefanoni et al., 2011; Hernández-Stefanoni et al., 2014). Management and monitoring of forest is therefore, is important for reducing the rate of increased $\mathrm{CO} 2$ in the atmosphere. The main aim of forest management is to increase vegetation so that the amount of carbon may increase. The carbon pool in vegetation can be

*Corresponding author: pawan2607@gmail.com 
accomplished through protecting degraded forest to get the maximum value of carbon sequestration (Kallur, 2003). Agro forestry programme by bringing non-forested areas under forest is indicative of accomplishing such task. Forest transformation is the major source of anthropogenic induced carbon dioxide emissions and is responsible for generating nearly 10 to 25\% CO2 globally (Muñoz et al., 2010).

Sariska National Park situated in Rajasthan was and still an excellent wildlife habitat and is a rich heritage site, but due to poor protection the number of tigers started dwindling in the middle 1990s. The primary reason for the cruel culling of the tigers in Sariska was human-caused conflict, and this has not been fully redressed as yet. Due to availability of sufficient prey base in the Reserve, man-animal conflict does not exist as such. Anthropogenic conflicts arise due to commercial poaching of tigers which led to their disappearance from Sariska (Kumar et al., 2018a). There are several villages in the core of the Reserve. Relocation of some of them would effectively help the wildlife as well as villagers. As one of the last surviving forested tracts of its kind Sariska is currently a bitter battleground between environmentalists who wish to protect its biodiversity and developers who wish to exploit its wealth. In order to avoid the conflicts, strong management strategies should be undertaken (Kumar et al., 2018b). Suitable sites should be identified for development of wildlife habitat. Geospatial techniques provide a cost-effective and quick means to make these decisions. The parameters important for the suitable site selection depend on the literature survey, secondary data and field data.

Understanding threatened species is important in preventing their extinction and revitalizing their populations. Tigers have already been documented as threatened species and are on the verge of extinction. The tiger needs large undisturbed landscapes with ample prey to raise young and to maintain long term genetic and demographic viability. Sariska is highly suitable habitat for tigers and presently tigers have been relocated here (Anselin et al., 1989; Buckley, 1985; Carroll and Larson, 2008; Karanth et al., 2006). The study targets at determining suitable sites for tiger relocation in the area. Hence, ground truth and field survey regarding the land use/ land cover patterns and the terrain features of Sariska National Park are required. Secondary data regarding wildlife habitat is also required to show the prey-predator relationship in the park (Karanth and Nichols, 1998; Karanth and Nichols, 2000; Karanth and Nichols, 2002). A methodology integrating several forms of remotely sensed data into a Geographic Information Systems (GIS) model is developed that identifies suitable sites. The outcome may fit with conservation strategies of wildlife in the coming future to be taken by authorities.

Forest ecosystems are the precious resource providing wildlife habitat and daily supplies such as medicinal ingredients (Chundawat et al., 1999; Clark, 1990; ; Clark, 1993; Bradley and Fleishman, 2008; Brain et al., 2010). The tropical forest loss and fragmentation is one of the greatest threats to the world's biological diversity. In 1992, the convention on bio-diversity (CBD) highlighted some measures that must implement to conserve natural ecosystems. Specially for tropical forests, one inhabiting many species contributing to the high species richness in any of the ecosystems on earth. Out of these many species have been well studied, but there is little knowledge about ecological structure and functions (Karanth, 2007; Kideghesho et al., 2006; Kushwaha et al., 2004; lasgorceix and Kothari, 2009; Singh et al., 2009). The forest is a plant community naturally formed or both grown and mixed. Deforestation increases atmospheric $\mathrm{CO}_{2}$ and other trace-gases, ultimately changing climatic behavior, because the absorption of carbon is higher in forest region than in the other terrestrial regions which replace it. The amount of $\mathrm{CO}_{2}$ in the atmosphere is strong-minded by uninterrupted flow in the middle of the stores of carbon in the ocean, the earth's biological systems, the atmosphere, and its geological resources.

\section{Study Area}

The Sariska Tiger Reserve (STR), is a part of Sariska Wildlife Sanctuary in the Alwar district of Rajasthan (Kumar et al., 2014a). STR stretching for $1200 \mathrm{~km}^{2}$ is located between $27^{\circ} 13^{\prime} \mathrm{N}$ to $27^{\circ} 31^{\prime} \mathrm{N}$ latitudes and from $76^{\circ} 15^{\prime} \mathrm{E}$ to $76^{\circ} 33^{\prime} \mathrm{E}$ longitudes (Figure 1). Government of Rajasthan (2007) notified three distinct zones in STR viz. critical tiger habitat $\left(881.11 \mathrm{~km}^{2}\right)$, protected forest $\left(276.14 \mathrm{~km}^{2}\right)$ and reserved forest $\left(604.97 \mathrm{~km}^{2}\right)$. Sariska Tiger Reserve was part of Alwar princely state before the socio-political integration of India after Independence. Government of Rajasthan 
(GoR) took flagship control over Reserve and declared it Wildlife Reserve Area under Rajasthan Wild Animals and Birds Protection Act (1951). Initially it was called Sariska National Park which was brought under Project Tiger in the second phase of the project expansion in 1978-79 and henceforth declared as Tiger Reserve. Approximately $800-1000 \mathrm{~km}^{2}$ area to be allocated looking at the tiger life history, population viability analysis, etc by National Tiger Conservation Authority which is a statutory body exercising its power under Wildlife (Protection) Act 1972. Of the total area of STR $\left(1200 \mathrm{~km}^{2}\right)$, about $881 \mathrm{~km}^{2}$ area has been notified as critical habitat, $604.97 \mathrm{~km}^{2}$ area under Reserved Forest and $276.14 \mathrm{~km}^{2}$ area under Protected Forest category by GoR in 2007 based on MoEF norms. The STR has identified three core areas on the basis of vegetation and tiger habitat suitability: core I $\left(273.8 \mathrm{~km}^{2}\right)$, core II $\left(126 \mathrm{~km}^{2}\right)$ and core III $\left(97.5 \mathrm{~km}^{2}\right)$. Sariska Tiger Reserve has six ranges: Sariska, Akbarpur, Ajabgarh, Alwar buffer, Talvriksh and Tehla. These ranges are further divided into 84 beats: Tehla range (20 beats), Sariska range (19 beats), Akbarpur range (17 beats), Alwar Buffer (15 beats), Talvriksh range (13 beats) and Ajabgarh (13 beats) (Kumar et al., 2014).

Geology of Sariska Tiger Reserve is dominated by Aravalli system and rocks of Delhi super group. Major rocks in these groups are granites, schist, quartzites, ultrabasic/ ultramafic, marble, limestone, etc. The area is composed of structural hills, denudation hills, curvilinear hills, residual hills, piedmont zone, etc. which are generally rocky areas of various natures and covered by variety of vegetation. Massive basalts in deccan traps flows along the border of Rajasthan and Madhya Pradesh. The soils of STR are fertile, dark and rich in minerals. The mineral deposit near Dariba was found to be considerably rich in copper ore. Copper ore is the most important mineral deposit occurring in the reserve. The Geological Survey of India drilled out nine test bores during 1972-73. The concentration of copper ore deposited was found to be uneconomic for commercial purposes (Rani et al., 2011).

The primary consumers found in STR are Sambhar, Nilgai, Chital, Wildboar and Chausingha. The Langur (Presbytis entellus Eschsch.) is common through forest but their concentration is near temples. Principle predators are Leopard (Panthera pardus L.) and Tiger
(Panthera tigris L.) in the study area. Important niches of tigers are Bandipur, Algwal, Tarunda, Tunda Chhalipaj, Chamoli, Slopka, Kalighati and Jahaj. Sariska is home to innumerable carnivores, including Rusty Spotted Cat (Prionailurus rubiginosus L.), Jackal (Canis aureus L.), Leopard (Panthera pardus L.), Caracal (Caracal caracal Schreb.), Jungle Cat (Felis chaus Schreb.), Tiger (Panthera tigris L.), Hyena (Hyaena hyaena) and Wild Dog (Cuon alpinus Pallas.). These predators feed on an abundance of prey species such as Sambar (Rusa unicolor Kerr.), Cheetal (Axis axis Erxleben.), Nilgai (Boselaphus tragocamelus Pallas.), Chausingha (Tetracerus quadricornis Blainville.), Wild Boar (Sus scrofa L.), Civet (Viverricula indica Dasmerest.), Palm Civet (Paradoxurus hermaphroditus Pallas.) Rhesus Monkeys (Macaca mulatta Zimmermann) are also found in Sariska in handy numbers around Talvriksh and near many temples. The avian world includes the Great Indian Horned Owl (Bubo bubo L.) Peafowl (Pavo cristatus L.), Grey Partridge (Perdix perdix L.), Golden backed Wood Pecker (Dinopium benghalense L.), Bush Quail (Perdicula asiatica Sykes.), Sand Grouse (Pterocles indicus Gmel.), Crested Serpent Eagle (Spilornischeela Latham) and Tree Pie (Dendrocitta vagabunda Latham) (Kumar et al., 2018a).

\section{MATERIALS AND METHODOLOGY}

\section{Data collection}

Multi spectral instrument (MSI) of Sentinel-2A satellite data with twelve spectral bands, 13 spectral channels, 10 meters spatial resolution was procured on September 2019 for developing NDVI indices of the sampled tree species. The effectiveness of Sentinel-2A data in monitoring land use at optimal ground resolution help in monitoring land use/land cover changes due to wildfire, forest change, drought, urbanization, climate change, etc. Atmospheric and geometric corrections of satellite image were carried out using image processing software ERDAS IMAGINE (v. 2014). False colour composite (FCC) was developed for interpretation of different land use/cover categories using element image interpretation. Delineated tree species on satellite image were verified with geo-tagged surface species through ground truth. 


\section{Data calibration}

For cloud screening, algorithm was calibrated (i.e. threshold and parameters were defined) based on an empirical approach using imagery dataset composed by a validation sub-set and a calibration sub-set. Calibration of the algorithms and the validation of the obtained products (bottom-of-atmosphere reflectance, aerosol optical thickness and water vapour content) were performed for atmospheric correction using a set of test sites representative of main surface atmosphere types (Kumar et al., 2018). Calibration was carried out for any correction in the values of parameters during launching and the in-orbit phase, and to correct the errors occurred due to navigation and surface topography during ortho-rectification process. TOA reflectance $(\rho)$ was obtained from each spectral band (k) and each pixel image (i,j) by its numeric digital counts (CN). This conversion was acquired into account the incoming solar direction by its zenith angle $\left(\theta_{s}\right)$ for each pixel, the equivalent extra-terrestrial solar spectrum $\left(E_{s}\right)$, and the absolute calibration $\left(A_{k}\right)$ of the instrument MS.

Where,

$\mathrm{CN}_{\mathrm{k}, \mathrm{NTDI}}=$ Equalized numeric digital count of the pixel (i,j) with NTDI,

\section{$\mathrm{E}_{\mathrm{s}}=$ Equivalent extra-terrestrial solar spectrum,}

The component $d(t)=$ Sun-Earth distance variation correction.

The intensity of light radiating from a point source is inversely proportional to the square of the distance from the source by inverse square law of irradiance.

Where:

$\mathrm{t}=$ Julian Day

$0.01673=$ Eccentricity of earth orbit.

$0.0172=$ Angular velocity of earth

\section{Method}

The corresponding weights for the parameters are defined by applying multi-criteria decision analysis (MCDA) wherein Analytical Hierarchy Process is applied. Seven data layers were used for the analysis: forest type and density, slope, settlements, waterholes, drainage and roads. Each data layer is reclassified with values that indicated the suitability of that data for tigers [best (5), worst (1)]; thereafter interpolated to ten priority classes.

\subsubsection{Analytical Hierarchy Process (Crisp and Fuzzy AHP)}

The analytic hierarchy proces s (AHP), also analytical hierarchy process, is a structured technique for organizing and analyzing complex decisions, based on mathematics and psychology. The method is based on the assumption of evaluation consistency; it also relies on the hypothesis that inconsistency occurs mainly in evaluations between alternatives of seemingly minor importance to the decision maker. By taking as its basis alternatives of apparent greater importance, the method makes a more careful analysis when comparing these alternatives with the other ones. Thus, it is proposed that for each calculation of priorities in each criterion, the alternative that the decision maker considers the most or one of the most important alternatives is taken as the basis of comparison. Different levels of uncertainty of Analytical Hierarchy Process (AHP) are used to assign weights to the parameters including Knowledge-based, Crisp AHP, Fuzzy AHP Triangular and Fuzzy AHP Narrow Trapezoidal. Pairwise Comparison Method (PCM) and Reciprocal matrix are shown in table 1 and 2.

Table 1: Pair wise Comparison Method (PCM).

\begin{tabular}{|l|l|}
\hline $\begin{array}{l}\text { Intensity of } \\
\text { importance }\end{array}$ & $\begin{array}{l}\text { Verbal judgment } \\
\text { of preference }\end{array}$ \\
\hline 1 & Equal Importance \\
\hline 3 & Moderate importance \\
\hline 5 & Strong importance \\
\hline 7 & Extreme importance \\
\hline 9 & Extremely more important \\
\hline $2,4,6,8$ & $\begin{array}{l}\text { Intermediate values between } \\
\text { adjacent scale values }\end{array}$ \\
\hline
\end{tabular}

\section{RESULTS}

The first parameter found responsible for suitable tiger habitats is the forest type and vegetation canopy density. With nearly $50 \%$ forest covering the study 
Table 2: Reciprocal matrix

\begin{tabular}{|c|c|c|c|c|c|c|c|}
\hline $\begin{array}{l}\text { Reciprocal } \\
\text { matrix }\end{array}$ & $\begin{array}{c}\text { Forest } \\
\text { type }\end{array}$ & $\begin{array}{l}\text { Forest } \\
\text { density }\end{array}$ & Settlement & Water hole & Drainage & Road & Slope \\
\hline Forest type & 1 & 3 & 3 & 3 & 3 & 5 & 7 \\
\hline Forest density & $1 / 3$ & 1 & & & & & \\
\hline Settlement & $1 / 3$ & & 1 & & & & \\
\hline Water hole & $1 / 3$ & & & 1 & & & \\
\hline Drainage & $1 / 3$ & & & & 1 & & \\
\hline Road & $1 / 5$ & & & & & 1 & \\
\hline Slope & $1 / 7$ & & & & & & 1 \\
\hline
\end{tabular}

area, most of the area is under open and moderately dense forests.

\section{Land use and land cover}

Land use/land cover maps of 2017 imagery were prepared after classifying, interpretation and verifying it with ground truth data. Land comprised of soil, water and vegetation is one of the important natural resources of the ecosystem. Land use and land cover are essential elements for understanding and modelling the earth feature system. The information derived through land use land cover analysis can be helpful in planning and management of resources. The term land use is generally used for specific utilization of land by human being while land cover relates the features on the earth surface. LU/LC cover inventory provides understanding of utilization of land under specific use and helps in planning, sutainable development and management. Land cover maps are presently being developed from local to national to global scales. Land use is determined by climate, relief, soil and natural vegetation. All economic activities like agriculture, industrial development and energy production are heavily relied on characteristics of land resource.

LU/LC map prepared using sentinel-2A data. Base map was prepared using topographic sheet and was over laid on satellite data. Interpretation keys were prepared using elements of image interpretation and ground truthing. The major land use/land cover classes included dense forest, open forest, scrub land, barren land, water bodies and built up in STR (Table 3 and Figure 1)

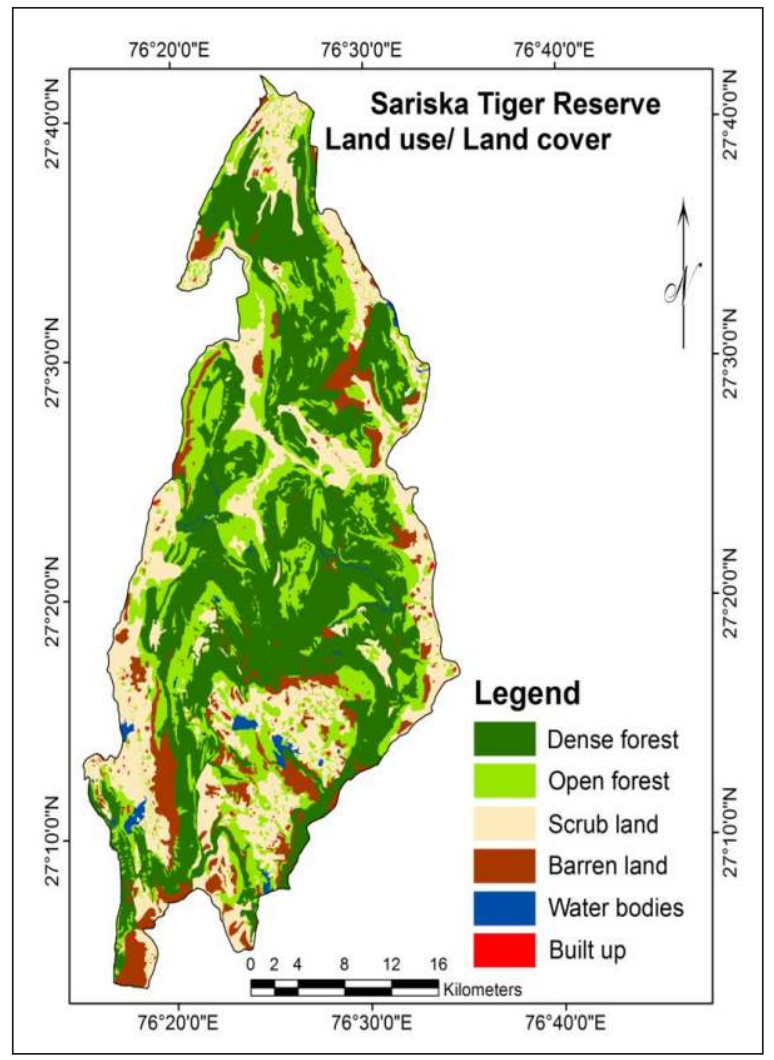

Figure 1: Land use/land cover in STR.

Total area under forest was $61.38 \%$. Of this, largest area was under dense forest (53.11\%) followed by open forest (8.27\%). Area under scrub land use was (26.63\%). It included agriculture, grasses and scrubs. Nearly 09.09\% area was under barren land, 02.11\% area was under built up and only $0.79 \%$ area was under water bodies. 
Table 3: Land use/land cover classes in STR.

\begin{tabular}{|l|c|c|}
\hline LULC classes & Area $\mathbf{( k m 2 )}$ & Area (\%) \\
\hline Dense forest & 628.488 & 53.11 \\
\hline Open forest & 97.914 & 8.27 \\
\hline Scrub land & 315.195 & 26.63 \\
\hline Barren land & 107.579 & 9.09 \\
\hline Water bodies & 9.293 & 0.79 \\
\hline Built up & 24.987 & 2.11 \\
\hline
\end{tabular}

\section{Parameters for determining tiger} habitat suitability

Habitat suitability map of tiger (Fig. 3) is obtained by GIS-MCDA using thematic map parameters as inputs applying fuzzy AHP (FAHP) Triangular method, for assigning weights and finally modeled in ERDAS Imagine. The final map is then reclassified into five suitability classes (Class 1 to 5). In order to validate the results, GPS locations of the tiger presence was obtained from Principal Chief Conservator of Forest (PCCF), Jaipur, Rajasthan, to construct the point map illustrating the location of tigers reintroduced during 2008. As shown in Table 4, AHP parameter was calculated to in presence and absence of human settlements respectively. Different parameters for determining tiger habitat suitability in core I zone (Figure 2).

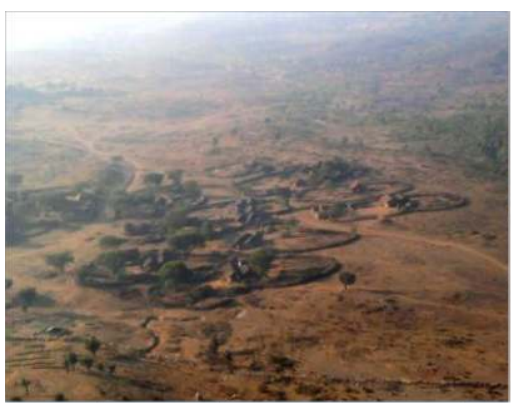

Settlement in Core zone I

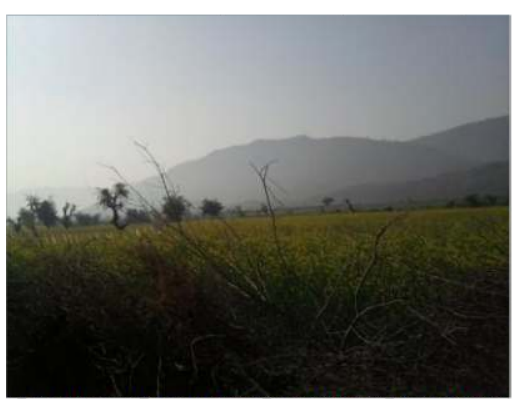

Crop land in Buffer zone

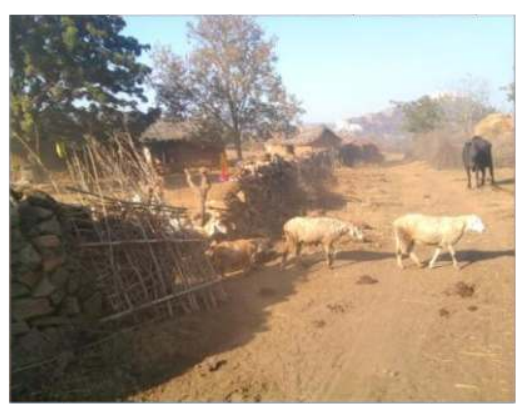

Encroachments in Core zone I

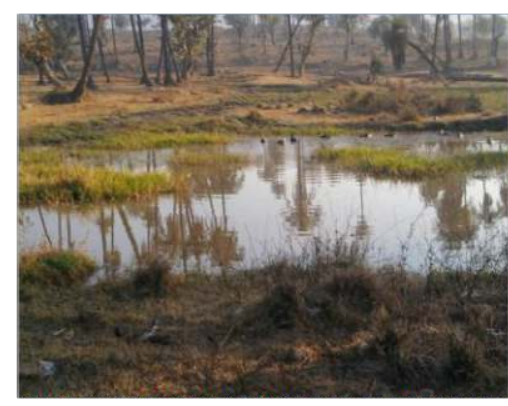

Waterbody in Core zone I

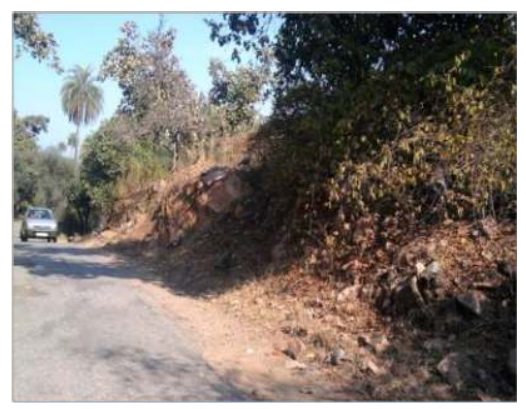

Road in Core zone I

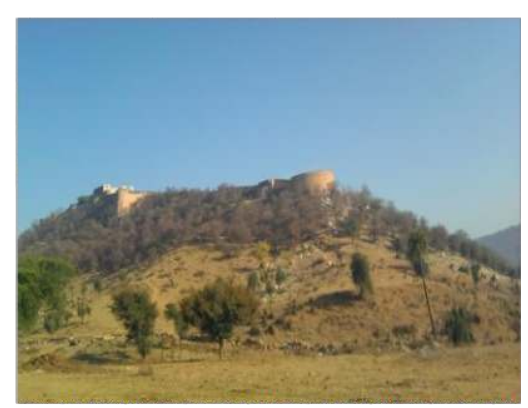

Fort to be transformed into hotel in Core zone

Figure 2: Parameters for determining tiger habitat suitability 


\section{Distance allocation and buffer maps}

The Spatial Analyst extension provides several sets of tools that can be used in proximity analysis. The Distance toolset contains tools that can be used to determine distance and nearness to source features. Buffer is one of the easiest tools to understand and one of the most commonly used. It is a quick and easy way to to determine both if and how much/many features are found within a certain distance of another feature. For feature data, the tools found in the Proximity toolset can be used to discover proximity relationships. These tools output information with buffer features or tables. Distance allocation and buffer maps are shown in figure 3.

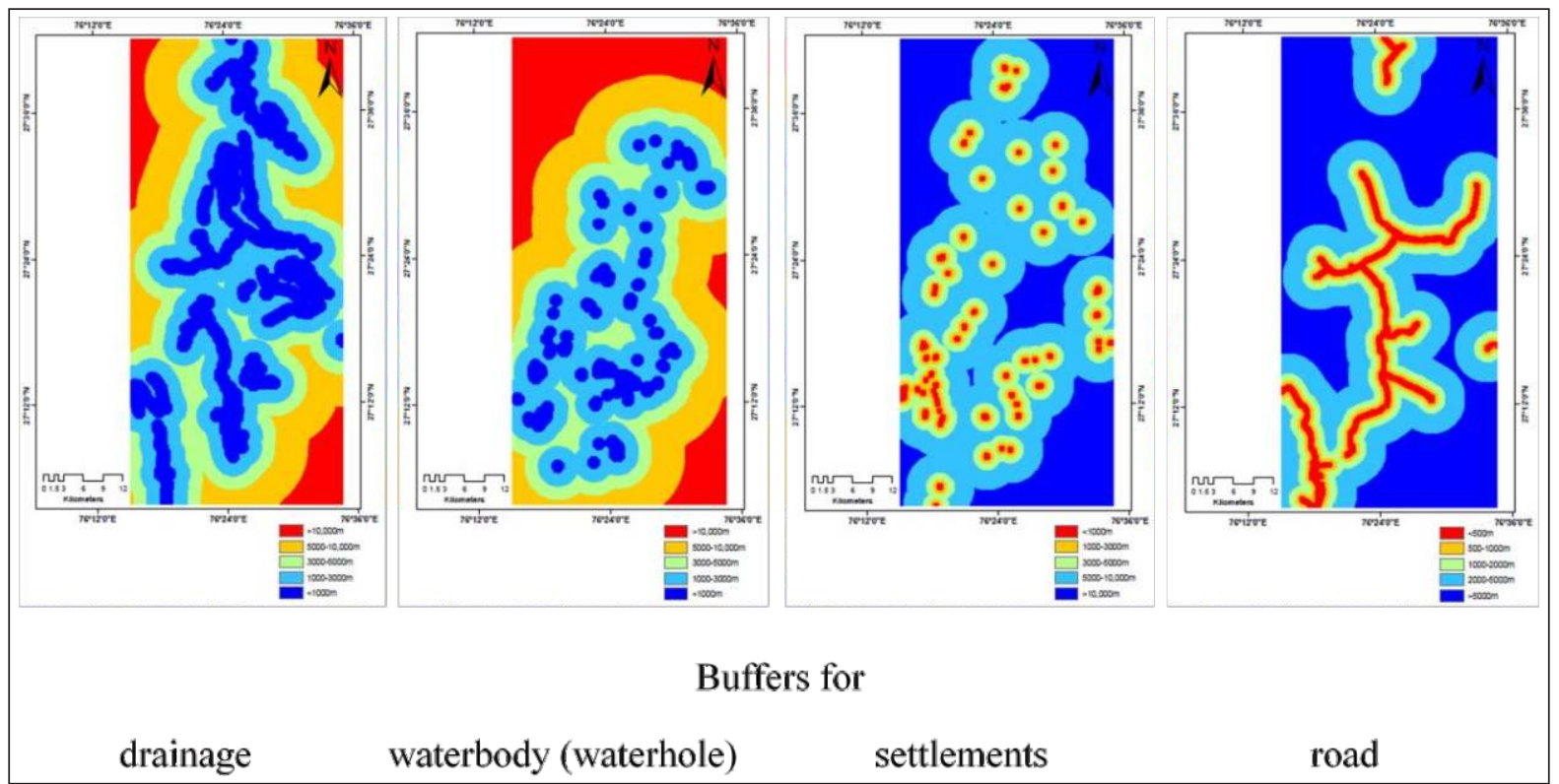

Figure 3: Distance allocation and buffer maps

\section{Interpolation}

Interpolation is the process of estimating unknown values that fall between known values. Spatial interpolation calculates an unknown value from a set of sample points with known values that are distributed across an area. The distance from the cell with unknown value to the sample cells contributes to its final value estimation. Knowledge-based, Crisp AHP, Fuzzy AHP Triangular and Fuzzy AHP Narrow Trapezoidal interpolation map shown in figure 4.

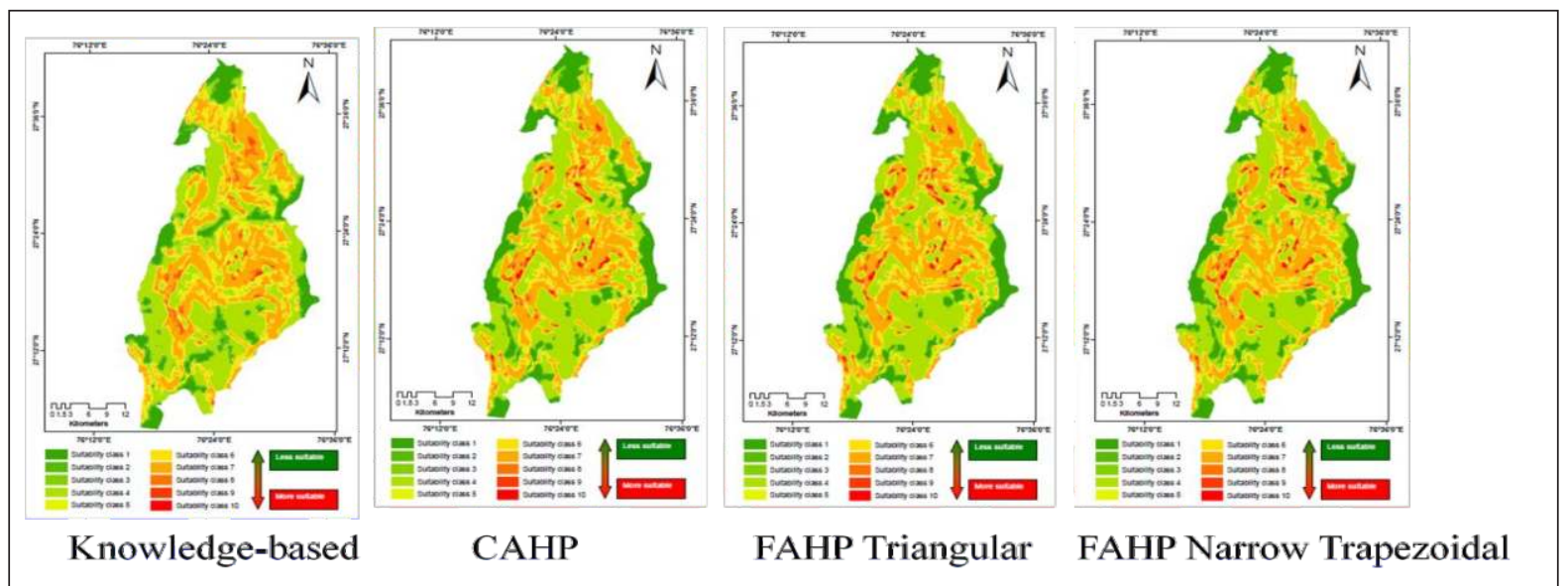

Figure 4: Interpolation (weighted mean overlay). 


\section{Habitat Suitability Index}

Habitat Suitability Index (HIS) confirms the increase in habitat suitability of the tiger in absence of human settlements. The HSI map as obtained is shown in Fig. 3 from which the spatial information related to tiger habitats can be obtained which in turn can help in formulating conservation strategies. Sinha et al. (2011a) found similar results using GIS-MCDA but crisp AHP was used in the analysis. In another study by Sinha et al. (2011b), it is observed that fuzzy logic implemented in AHP could give better results in realworld situations. The mean HSI is $0.546 \pm 0.0005$. HSI $>0.8$ corresponding to classes 8 to 10 occupies nearly $3.8 \%$ of the total study area on an average. the area covered in each suitability class is shown in the table 4 and figure 5.
Table 4: AHP parameter

\begin{tabular}{|l|l|}
\hline Parameters & AHP $\lambda \mathbf{m a x}$ \\
\hline Vegetation type & 0.331555 \\
\hline Vegetation density & 0.09202 \\
\hline Settlement & 0.121896 \\
\hline Waterholes & 0.18736 \\
\hline Drainage & 0.18736 \\
\hline Road & 0.054118 \\
\hline Slope & 0.02569 \\
\hline
\end{tabular}

Figure 5: Potential suitable tiger relocation sites in the core zone I and area adopted by tigers. 


\section{CONCLUSION}

This study highlights the impact of adding uncertainty or fuzziness when selecting the most suitable sites for tiger relocation in the Sariska Wildlife Reserve using the Analytic Hierarchy Process (AHP) within multicriteria based Geographic Information System (GIS). Fuzzy AHP that incorporates a Wide Trapezoidal level of uncertainty is found to generate more variability in map outputs compared to lesser levels of uncertainty. The relative difference between crisp (CAHP) and fuzzy (FAHP) AHP averages 2.7\%, although with certain types of uncertainty it can reach up to $5 \%$. ANOVA also shows better results for increased levels of uncertainty compared to lesser ones. The method adopted in the study can effectively handle the uncertainty issue, and it can act as a useful tool for wildlife habitat evaluation and management. The area is found to be highly suitable for tiger habitat and suitable for their relocation. HSI > 0.8 corresponds to $49.057 \mathrm{~km}^{2}$ which is the most suitable for tiger habitat corresponding to $3.8 \%$ of the total study area on an average.

\section{REFERENCES}

1. Anselin, A., Meire, P. M., \& Anselin, L. (1989). Multicriteria techniques in ecological evaluation: an example using the analytical hierarchy process. Biological Conservation, 49(3), 215-229.

2. Bradley, B. A., \& Fleishman, E. (2008). Can remote sensing of land cover improve species distribution modelling?. Journal of Biogeography, 35(7), 1158-1159.

3. Halstead, B. J., Wylie, G. D., \& Casazza, M. L. (2010). Habitat suitability and conservation of the giant gartersnake (Thamnophis gigas) in the Sacramento Valley of California. Copeia, 2010(4), 591-599.

4. Buckley, J. J., Feuring, T., \& Hayashi, Y. (2001). Fuzzy hierarchical analysis revisited. European Journal of Operational Research, 129(1), 48-64.

5. Carroll, C., \& Larson, C. (2008). Modeling Potential Tiger Habitat in Hupingshan-Houhe and Mangshan-Nanling National Nature Reserves, China. Atlas of Maine, 2008(2), 9.

6. Chundawat, R. S., Gogate, N., \& Johnsingh, A. J. T. (1999). Tigers in Panna: preliminary results from an Indian tropical dry forest. Riding the tiger: tiger conservation in human-dominated landscapes, 123-129.

10. Clark, C. D. (1990). Remote sensing scales related to the frequency of natural variation-An example from paleo-ice-flow in Canada. IEEE Transactions on Geoscience and Remote Sensing, 28, 503-508.

11. Clark, J. D., Dunn, J. E., \& Smith, K. G. (1993). A multivariate model of female black bear habitat use for a geographic information system. The Journal of wildlife management, 519-526.

12. Goodale, C. L., Apps, M. J., Birdsey, R. A., Field, C. B., Heath, L. S., Houghton, R. A., ... \& Shvidenko, A. Z. (2002). Forest carbon sinks in the Northern Hemisphere. Ecological applications, 12(3), 891-899.

13. Hernández-Stefanoni, J. L., Dupuy, J. M., Johnson, K. D., Birdsey, R., Tun-Dzul, F., Peduzzi, A., ... \& López-Merlín, D. (2014). Improving species diversity and biomass estimates of tropical dry forests using airborne LiDAR. Remote Sensing, 6(6), 4741-4763.

14. Hernández-Stefanoni, J. L., Gallardo-Cruz, J. A., Meave, J. A., \& Dupuy, J. M. (2011). Combining geostatistical models and remotely sensed data to improve tropical tree richness mapping. Ecological Indicators, 11(5), 10461056.

15. Houghton, R. A., Hall, F., \& Goetz, S. J. (2009). Importance of biomass in the global carbon cycle. Journal of Geophysical Research: Biogeosciences, 114 (G2).

16. Kawanishi, K., \& Sunquist, M. E. (2004). Conservation status of tigers in a primary rainforest of Peninsular Malaysia. Biological Conservation, 120(3), 329-344.

17. Karanth, K. K. (2007). Making resettlement work: the case of India's Bhadra Wildlife Sanctuary. Biological Conservation, 139(3-4), 315-324.

18. Karanth, K. K., Curran, L. M., \& ReuningScherer, J. D. (2006). Village size and forest disturbance in Bhadra wildlife sanctuary, Western Ghats, India. Biological conservation, 128(2), 147-157.

19. Karanth, K. U., Nichols, J. D., Kumar, N. S., Link, W. A., \& Hines, J. E. (2004). Tigers and their prey: predicting carnivore densities from 
prey abundance. Proceedings of the National Academy of Sciences, 101(14), 4854-4858.

20. Karanth, K. U., \& Nichols, J. D. (1998). Estimation of tiger densities in India using photographic captures and recaptures. Ecology, 79(8), 2852-2862.

21. Karimi, A. R., Mehrdadi, N., Hashemian, S. J., Nabi-Bidhendi, G. R., \& TavakkoliMoghaddam, R. (2011). Using of the fuzzy TOPSIS and fuzzy AHP methods for wastewater treatment process selection. International journal of academic research, 3(1).

22. Kideghesho, J. R., Nyahongo, J. W., Hassan, S. N., Tarimo, T. C., \& Mbije, N. E. (2006). Factors and ecological impacts of wildlife habitat destruction in the Serengeti ecosystem in northern Tanzania. African Journal of Environmental Assessment and Management, 11, 17-32.

23. Kushwaha, S. P. S., Khan, A., Habib, B., Quadri, A., \& Singh, A. (2004). Evaluation of sambar and muntjak habitats using geostatistical modelling. Current Science, 1390-1400.

24. Lasgorceix, A., \& Kothari, A. (2009). Displacement and relocation of protected areas: a synthesis and analysis of case studies. Economic and political weekly, 37-47.

25. Muñoz, C., Paulino, L., Monreal, C., \& Zagal, E. (2010). Greenhouse gas (CO2 and N2O) emissions from soils: a review. Chilean journal of agricultural research, 70(3), 485-497.

26. Swenson, N. G. (2008). The past and future influence of geographic information systems on hybrid zone, phylogeographic and speciation research. Journal of evolutionary biology, 21(2), 421-434.

27. Kumar, P., Sajjad, H., Tripathy, B. R., Ahmed, R., \& Mandal, V. P. (2018). Prediction of spatial soil organic carbon distribution using Sentinel-2A and field inventory data in Sariska Tiger Reserve. Natural Hazards, 90(2), 693-704.

28. Kumar, P., Sajjad, H., Mahanta, K. K., Ahmed, R., \& Mandal, V. P. (2018). Assessing suitability of allometric models for predicting stem volume of Anogeissus pendula Edgew in sariska Tiger Reserve, India. Remote Sensing Applications: Society and Environment, 10, 47-55.
29. Kumar, P., Tomar, V., Srivastava, P., Singh, J., \& Gupta, G. (2014). Geospatial approach for carbon sink in the timbered biomass for tropical wildlife reserve. Asian Journal of Geoinformatics, 14(1).

30. Kumar, P., Pandey, P. C., Kumar, V., Singh, B. K., Tomar, V., \& Rani, M. (2014). Efficient recognition of forest species biodiversity by inventory-based geospatial approach using LISS IV sensor. IEEE Sensors Journal, 15(3), 18841891.

31. Rani, M., Kumar, P., Yadav, M., \& Hooda, R. S. (2011). Role of geospatial techniques in forest resource management of Sariska Tiger Reserve (Rajasthan), India. New York Science Journal, 4(6), 77-82.

32. Sharma, L. K., Kanga, S., Nathawat, M. S., Sinha, S., \& Pandey, P. C. (2012). Fuzzy AHP for forest fire risk modeling. Disaster Prevention and Management: An International Journal.

33. Sinha, S., Sharma, L. K., Pandey, P. C., Nathawat, M. S., \& Kanga, S. (2011). Impact of human intrusion on tiger habitat and conservation using integrated geospatial techniques. Int. J. Earth Sci. Eng, 4(3), 39-45.

34. Sinha, S., Sharma, L. K., \& Nathawat, M. S. (2011). Retrieving tiger habitats: Conserving wildlife geospatially. Appl. Remote Sens. J, 2(1), 1-5.

35. Sinha, S., Sharma, L. K., \& Nathawat, M. S. (2012). Tigers losing grounds: impact of anthropogenic occupancy on tiger habitat suitability using integrated geospatial-fuzzy techniques. The Ecoscan, 1, 259-263.

36. Sinha, S., Nathawat, M.S. and Sharma, L.K. (2014). Geospatial approach for managing relocation and distribution of tigers. Rusu, I. (Ed.). LAP Lambert Academic Publishing, Germany. pp. 205.

37. Sinha, S. (2016). Integrated GIS and Multi Criteria approach for the wildlife habitat suitability. Journal of Advanced Research in Geo Sciences \& Remote Sensing, 3: 1-16.

38. Singh, R., Joshi, P. K., Kumar, M., Dash P. P. and Joshi, B. D. 2009. Development of tiger habitat suitability model using geospatial toolsa case study in Achankmar Wildlife Sanctuary 
(AMWLS), Chhattisgarh India. Environ. Monit. Assess. 155: 555-567.

39. Tanushree, S. (2009). Relocation of villages in Sariska Tiger Reserve. Current Science, 97(10), 1399-1400.

40. Vahidnia, M. H., Alesheikh, A., Alimohammadi, A., \& Bassiri, A. (2008). Fuzzy analytical hierarchy process in GIS application.
The International Archives of the Photogrammetry, Remote Sensing and Spatial Information Sciences, 37(B2), 593-596.

41. Wuver, A. M. (2006). The impact of human activities on biodiversity conservation in a coastal wetland in Ghana. West African Journal of Applied Ecology, 9(1). 